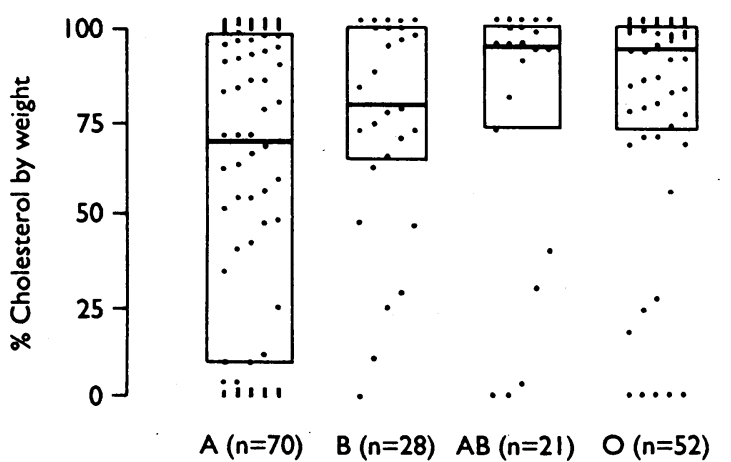

Blood group

Gall stone cholesterol content by $A B O$ phenotype in 171 patients with symptomatic gall stone disease. Data points, medians, and interquartile ranges are shown ( $p=0.02$ for difference between groups (KruskalWallis test))

smaller size. The incidence of cholesterol stones (49\%) in group A was lower than the average for Western countries $(70-80 \%)$.

Abnormalities in the metabolism of lipids, biliary cholesterol supersaturation, and serum lipid concentrations may have a role in lithogenesis. ${ }^{14}$ Though total serum cholesterol concentrations did not vary according to $\mathrm{ABO}$ phenotype, there was more coronary heart disease among group A patients.

Since previously established risk factors for gall stone disease were evenly distributed among the different blood groups, such factors should not have appreciably confounded the associations reported. However, the mechanism responsible for blood type associations remains unclear. $\mathrm{ABO}$ antigens have previously been shown to be associated with development of cancer and cellular differentiation, ${ }^{5}$ and $\mathrm{ABO}$ blood group determinants and the pattern of epithelial cell glycosylation may also alter the basic events associated with lithogenesis.

The present hypothesis should be considered when evaluating factors triggering gall stone formation in humans and when studying the genetic determinants of cholesterol cholelithiasis.

We thank Dr Lauri H J Lajunen, department of chemistry, University of Oulu, for help with the infrared spectrometric analyses.

1 Whincup PH, Cook DG, Phillips AN, Shaper AG. ABO blood group and ischaemic heart disease in British men. BMF 1990;300:1679-82.

Beardmore JA, Karimi-Booshehri F. ABO genes are differentially distributed in socioeconomic groups in England. Nature 1983;303:522-4.

3 Maclure KM, Hayes KC, Colditz GA, Stampfer MJ, Speizer FE, Willet WC. Weight, diet, and the risk of symptomatic gallstones in middle-aged women. WEngl, diet, and the risk of sym $1989 \cdot 321: 563-9$.

4 Busch N, Matem S. Current concepts in cholesterol gallstone pathogenesis. Eur f Clin Invest 1991;21:453-60.

5 Lee JS, Ro JY, Sahin AA, Hong WK, Brown BW, Mountain CF, et al. Expression of blood group antigen $\mathrm{A}-\mathrm{a}$ favourable prognostic factor in nonsmall-cell lung cancer. $N$ Engl $\mathcal{F}$ Med 1991;324:1084-90.

(Accepted 20 March 1992)

\section{Utilisation of medical care by abused women}

\section{B Bergman, B Brismar, C Nordin}

Department of Psychiatry, Karolinska Institute, Huddinge Hospital, S-141 86 Huddinge, Sweden

B Bergman, chief physician C Nordin, senior lecturer

Department of Surgery, Huddinge Hospital

B Brismar, senior lecturer

Correspondence and requests for reprints to: Dr Bergman.

$B M \mathcal{F}$ 1992;305:27-8 different age groups.
The typical injury pattern of battered wives described by Gayford and others includes bruises, lacerations, fractures, and haematoma. ${ }^{12}$ Most studies of abused women are not based on women seeking hospital care but on women in shelters. Although the medical services have an important mission in treating the traumatic injuries arising from physical abuse, abused wives appearing as inpatients as a result of nontraumatic diseases, and the medicosocial problems accompanying family violence, have been given little attention. This paper aims at describing the utilisation of inpatient medical care not only for traumatic injuries but also for medical, surgical, gynaecological, and undefined diseases, by abused women and controls in

\section{Subjects, methods, and results}

During an eight month period in 1983-4 an emergency room project at the Huddinge Hospital

Admissions to hospital for traumatic and non-traumatic diseases in abused women and controls of different age groups

\begin{tabular}{|c|c|c|c|c|}
\hline \multirow[b]{2}{*}{$\begin{array}{c}\text { Age } \\
\text { (years) }\end{array}$} & \multicolumn{2}{|c|}{$\begin{array}{l}\text { No of admissions for traumatic } \\
\text { diseases }\end{array}$} & \multicolumn{2}{|c|}{$\begin{array}{l}\text { No of admissions for } \\
\text { non-traumatic diseases }\end{array}$} \\
\hline & $\begin{array}{l}\text { Abused } \\
\text { women }\end{array}$ & Controls & $\begin{array}{l}\text { Abused } \\
\text { women }\end{array}$ & Controls \\
\hline $\begin{array}{c}<25 \\
25-29 \\
30-34 \\
35-39 \\
>40\end{array}$ & $\begin{array}{r}5 \\
5 \\
16 \\
12 \\
32\end{array}$ & $\begin{array}{l}5 \\
4 \\
4 \\
1 \\
4\end{array}$ & $\begin{array}{l}47 \\
49 \\
69 \\
61 \\
58\end{array}$ & $\begin{array}{l}29 \\
14 \\
13 \\
17 \\
23\end{array}$ \\
\hline Total & 70 & 18 & 284 & 96 \\
\hline
\end{tabular}

attempted to identify and support abused women seeking hospital care. A total of 117 women, 58 of whom were admitted as inpatients, reported injuries resulting from domestic violence by their husband or partner. The mean age at the time of the battering was 33 (SD 2, range 16-75) years.

The abused women were compared with a control group selected from the population register and matched pairwise for age and geographical area in Stockholm with the group of 117 battered women. The number of hospital admissions during the period from 10 years before to eight years after the battering (19731991) were obtained from Stockholm County Council's computer files. The initial 58 admissions of the abused women, as well as all admissions for childbirth, were excluded.

During the 18 year study period there were 468 admissions as inpatients owing to surgical, gynaecological, medical, traumatic, and unspecified disorders, 354 among abused women and 114 among controls. Seventy (20\%) abused women and $18(16 \%)$ controls were admitted because of traumatic injuries. Table I shows that the battered women had more admissions in all age groups than the controls, especially in the age span 30-39.

Eighty five of the abused women $(73 \%)$ had been admitted to the hospital at least once, compared with 50 of the control subjects (43\%). The highest number of admissions was 56 in the abused group; 32 abused women $(38 \%)$ had been admitted five times or more. In the control group one woman had been admitted 12 times and three women $(6 \%)$ had been admitted five times or more.

\section{Comment}

Abused women are high consumers of hospital care. This high utilisation of medical care could reflect the strife and violence going on at home, and traumatic injuries may not be the only consequences of this violence. As domestic violence often goes on for severa years, the overutilisation of care might be expected to 
be long standing. ${ }^{3}$ In our study more than a third of the abused women had been admitted five times or more.

The greater differences in admissions in the ages over 30 might be related to ongoing domestic violence. Several studies indicate that the risk of being the victim of wife beating is most pronounced in the fourth decade of life. ${ }^{124}$

The abused woman, in her exposed and desolate situation, does not always seek medical care for specific somatic diseases. ${ }^{3}$ The "battered wife syndrome" consists of somatic, psychosomatic, and psychiatric symptoms, and psychosocial support is an important reason for seeking hospital care.
Any physician should consider the possibility of ongoing domestic violence when confronted with a female patient lacking other obvious reasons for frequent hospital admissions.

1 Gayford JJ. Wife battering: a preliminary survey of 100 cases. BMJ $1975 ;$; : 194-7.

2 Gayford JJ. Battered wives. Med Science Law 1979;15:237-45.

3 Stark E, Flitcraft A, Frazier W. Medicine and patriarchal violence: the social construction of a "private" event. Int $\mathcal{F}$ Health Serv 1979;9:461-93.

4 Appleton W. The battered woman syndrome. Ann Emerg Med 1980;9:84-91.

5 Jaffe P, Wolfe D, Wilson S, Zak L. Emotional and physical health problems of battered women. Can f Psychiatry 1986;31:625-9.

(Accepted 2 April 1992)
Department of

Environmental and

Preventive Medicine,

Wolfson Institute of

Preventive Medicine,

Medical College of St

Bartholomew's Hospital,

London

Nicholas Wald, professor

Rossana Stone, laboratory

manager

Institute of Epidemiology and Health Services

Research, Department of

Clinical Medicine,

University of Leeds,

Leeds LS2 9LN

H S Cuckle, professor of

reproductive epidemiology

Department of Obstetrics and Gynaecology, Royal

London Hospital, London

J G Grudzinskas, professor

Department of Obstetrics and Gynecology, Institute of Human Genetics, Sheba Medical Centre, Tel-Hashomer, Israel Gad Barkai, senior lecturer

\section{Istituto Ostetrico}

Ginecologico " $L$

Mangiagalli," Seconda

Clinica, University of

Milan, Milan, Italy

Bruno Brambati, head of

prenatal diagnosis unit

Division of Immunology, State Serum Institute, Copenhagen, Denmark Borge Teisner, associate professor

\section{Institute for Human}

Genetics, University of

Giessen, Giessen,

Germany

Walter Fuhrmann, professor

Correspondence to:

Professor Wald.

BMF 1992;305:28

\section{First trimester concentrations of pregnancy associated plasma protein $A$ and placental protein 14 in Down's syndrome}

Nicholas Wald, Rossana Stone, H S Cuckle,
J G Grudzinskas, Gad Barkai, Bruno Brambati,
Borge Teisner, Walter Fuhrmann

Brambati et al reported that first trimester maternal serum concentrations of pregnancy associated plasma protein A (PAPP-A) were low in pregnancies associated with fetal aneuploidy. Of 13 pregnancies associated with Down's syndrome, seven were reported as having values less than or equal to the fifth centile. ${ }^{1}$ To examine the matter further and explore whether PAPP-A might be useful in screening for Down's syndrome in the first trimester we measured its concentration in sera previously used for measuring $\alpha$ fetoprotein, unconjugated oestriol, and human chorionic gonadotrophin concentrations in the first trimester. ${ }^{2}$ At the same time we investigated the endometrial protein known as placental protein 14 (PP14) as a possible additional first trimester serum marker.

\section{Subjects, methods, and results}

Serum samples were available from 19 of the 22 women with Down's syndrome pregnancies previously studied and 101 of the 108 original controls. The samples had been collected between 9 and 12 weeks' gestation and had been stored frozen in serum banks (United Kingdom, three cases; Israel, four cases; Germany, five cases; Italy, seven cases). Samples had been taken routinely from antenatal patients in the United Kingdom and immediately before chorionic villus sampling in the other countries. Cases and controls were similar with respect to gestational age and duration of storage of the serum sample and were balanced with respect to country of origin. Analysis of placental protein 14 required a larger volume of serum, and sufficient material was available for only 11 cases of Down's syndrome and 64 controls. PAPP-A was measured by radioimmunoassay at the Royal London Hospital using a specific antibody (Dako, High Wycombe, United Kingdom) and purified PAPP-A prepared at the University of Odense, Denmark. Placental protein 14 was measured by radioimmunoassay with an antibody provided by $\mathrm{Dr} \mathrm{H}$ Bohn

We expressed results for PAPP-A in multiples of the control group median (MoM) using the overall median concentration for all the unaffected pregnancies without adjustment for gestation since there was no significant relation between concentration and gestational age. Concentration of PAPP-A was significantly lower in the women with Down's syndrome pregnancies than in the controls $(p<0.001$, Wilcoxon signed rank test) (figure). The median MoM was 0.23 (95\% confidence interval 0.17 to 0.46$)$ in the cases of Down's syndrome; 12 of the 19 women with affected pregnancies $(63 \%)$ had values below the 10th centile value for the controls.
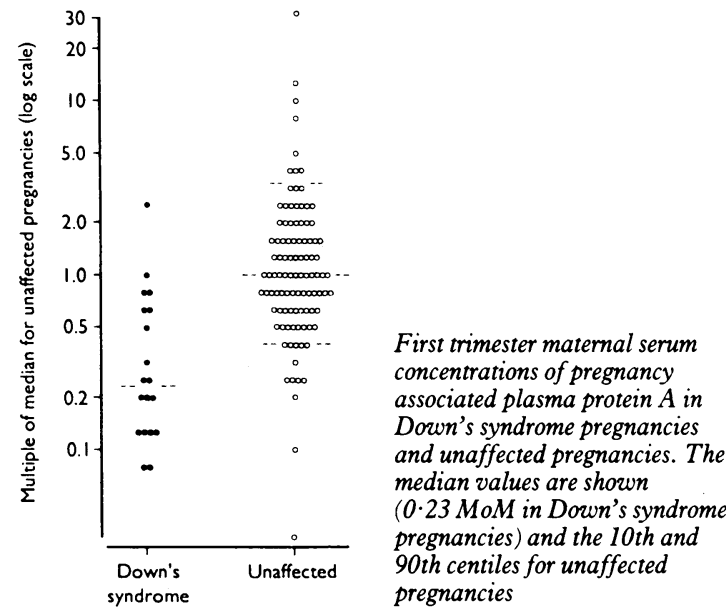

Placental protein 14 results were expressed in MoMs calculated from a weighted $\log$-linear regression of the median concentration for each completed week of pregnancy on gestational age. The concentrations in women with affected pregnancies were similar to those in women with unaffected pregnancies (median value $0.93 \mathrm{MoM}$ ) with almost total overlap.

\section{Comment}

Our results show that PAPP-A is a useful first trimester serum marker for Down's syndrome. Measurement of serum PAPP-A concentration together with other markers and the use of maternal age may form the basis of effective first trimester screening for Down's syndrome.

We thank Lynne George for performing the PAPP-A assays and Professor T Chard for suggesting the assay of PP14, which was performed in the department of reproductive physiology at St Bartholomew's Hospital. We also thank David Smith for help with computing.

1 Brambati B, Lanzani A, Tului L. Ultrasound and biochemical assessment of first trimester of pregnancy. In: Chapman M, Grudzinskas G, Chard T, eds. The embryo: normal and abnormal development and growth. London: SpringerVerlag, 1990:181-94.

2 Cuckle HS, Wald NJ, Barkai G, Fuhrmann WA, Altland K, Brambati B, et al. First trimester biochemical screening for Down's syndrome. Lance 1988;ii:851-2.

(Accepted 18 March 1992) 